092

Received: June 12, 2009

Accepted: November 10, 2009
Macedonian Journal of Animal Science, Vol. 2, No. 2, pp. 139-142 (2012)

In print ISSN $1857-6907$

On line ISSN $1857-7709$

UDC: 637.62(496.5)

Short communication

\title{
PHYSICOCHEMICAL COMPOSITION, PROPERTIES AND TECHNOLOGICAL CHARACTERISTICS OF SHEEP MILK FROM THE CAUCASIAN AND THE ASKANIAN BREEDS
}

\author{
Neviana Stancheva ${ }^{1}$, Genoveva Staikova ${ }^{1}$, Nikolina Naydenova ${ }^{2}$ \\ ${ }^{1}$ Agricultural Institute, Blvd. Simeon Veliki 3, Shumen, 9700, R. Bulgaria \\ ${ }^{2}$ Trakia University, Stara Zagora, R. Bulgaria \\ nevqna_68@abv.bg
}

\begin{abstract}
A study on the physicochemical composition, the properties, and the technological characteristics of sheep milk was carried out. The subject of the study was the milk produced by the Caucasian and the Askanian sheep breeds on the farm of "Kabiuk", near Shumen, during the lactation period of 2008. It was established that the quality components of the milk of the Caucasian and Askanian sheep are in keeping with the standards for raw sheep milk to be processed to dairy products. The technological characteristics indicate that the Caucasian and the Askanian sheep milk is a favourable environment for the development of the leaven bacteria cultures, rendering it an appropriate source for the Bulgarian Yoghurt industry.
\end{abstract}

Key words: fine-fleece sheep; milk; composition; properties; technological characteristics

\section{ФИЗИЧКО-ХЕМИСКИ СОСТАВ, СВОЈСТВА И ТЕХНОЛОШКИ КАРАКТЕРИСТИКИ НА ОВЧО МЛЕКО ДОБИЕНО ОД РАСИТЕ КАВКАСКА И АСКАНСКА}

\begin{abstract}
Извршено е испитување на физичко-хемискиот состав, својствата и технолошките карактеристики на овчото млеко. Предмет на истражувањето беше млекото добиено од кавкаската и асканската раса овци на фармата Кабиук во близина на Шумен за време на лактација во 2008 година. Се констатира дека квалитетните компоненти на млекото од кавкаската и асканската раса овци се во согласност со стандардите за суровото овчо млеко да биде преработено во млечни производи. Технолошките карактеристики укажуваат дека млекото од кавкаската и асканската овца е погодна средина за развој на квасните бактериски култури, правејќи го соодветен извор за бугарската индустрија за јогурт.
\end{abstract}

Клучни зборови: тенкорунеста овца; млеко; состав

\section{INTRODUCTION}

The Caucasian and the Askanian sheep breeds have played an essential role in the process of creation of all Bulgarian fine-fleece breeds. At present, though dramatically reduced in number, the nationally preserved breeds constitute a precious genetic pool. The studies of Boikovski (1995), Stefanova (2000), Dimitrov (2001), Boikovski et al. (2003) and others treat chiefly the values of the traits of economic importance for these breeds.

Milk physicochemical composition and properties researches in the merino-type and fine- fleece sheep are scarce on both national and global scale. Investigations on composition and quality characteristics of the milk have been carried out by Pena Blanko (1985) in the Spanish Merino, Mroczkowski (1989) in the Polish Merino, Galatov (1991) in the Soviet Merino and the Australian Merino cross-breeds. In Bulgaria studies in finefleece sheep have been conducted by Stankov et al. (1998), Slavova et al. $(2000,2001)$ and Slavov et al. (2006).

The objective of the present study was to establish the physicochemical composition, the properties, and some quality characteristics of the milk of the Caucasian and the Askanian sheep. 


\section{MATERIAL AND METHODS}

The subject of the study was the milk produced by the Caucasian and the Askanian sheep breeds on the farm "Kabiuk", near Shumen, during the lactation period of 2008 .

Bulk milk samples have been taken monthly during the morning milking after tank-mixing with the evening milk, in accordance with the regulations for milk sampling.

The physicochemical properties of the milk samples were analyzed at the research Dairy Laboratory, department of "Animal Breeding - Ruminants and Dairy Science", Faculty of Agriculture, Trakia University, Stara Zagora. Natural sheep yoghurt was produced four times in laboratory conditions under an officially certified original technology. Samples for analysis were collected from the raw milk before pasteurization, 1 and $2 \mathrm{~h}$ after leaven introduction, and during the coagulation process.

The raw milk was tested for solids not fat, total proteins, milk fat, and dry matter on the instrument MilkoScan ${ }^{\mathrm{TM}} 104 \mathrm{~A} / \mathrm{S}$ (Foss Electric, Denmark), for specific gravity -according to the BNS 1110-73, the titratable acidity - by the Torner's procedure (BNS 1110-80), and the renneting ability - by the BDS 659-74. The milk was pasteurized $\left(95^{\circ} \mathrm{C} / 30 \mathrm{~min}\right)$, cooled down to $45^{\circ} \mathrm{C}$ and cultivated with 1.5-\%, 24-hr yoghurt leaven.

The milk 1 and $2 \mathrm{hr}$ after leaven introduction, during clotting, at hour 24, and at day 10 of storage was analyzed for titratable acidity by the Torner's procedure and qualified in accordance with BNS 12-82.

White brine cheese yield was calculated using empirical formulas (Chomakov et al., 2000).

All the data were analyzed using the statistical procedure described by Eftimov et al. (1972).

\section{RESULTS AND DISCUSSION}

The information about the milk composition and properties of the studied breeds is shown in Table 1. The lactic fat content is $9.95 \%$ in the Caucasian and $9.39 \%$ in the Askanian ewes. These values are higher than the results of Stancheva et al. $(2000,2001)$, reporting fat percentage of 8.03 to $8.35 \%$ for the Trakia FineFleece breed and the Askanian Merino. Milk fat was reported to be lower in the Soviet Merino and the Australian Merino cross-breeds (Galatov, 1991) and in the North-East Bulgarian Fine-Fleece breed and its crosses (Dimitrov, 2001; Slavov et al., 2006).

Table 1

Composition and properties of the studied sheep milk

\begin{tabular}{|c|c|c|c|c|c|c|c|c|}
\hline \multirow{3}{*}{ Traits } & \multicolumn{4}{|c|}{ Caucasian breed } & \multicolumn{4}{|c|}{ Askanian breed } \\
\hline & \multicolumn{8}{|c|}{ Components, $\%$} \\
\hline & $\bar{x}$ & $\mathrm{~S}$ & $\mathrm{C}$ & $\mathrm{E}$ & $\bar{x}$ & $\mathrm{~S}$ & $\mathrm{C}$ & $\mathrm{E}$ \\
\hline Fat & 9.953 & 0.261 & 2.62 & 1.854 & 9.393 & 0.437 & 4.65 & 3.286 \\
\hline Total proteins & 6.040 & 0.248 & 4.10 & 2.899 & 6.080 & 0.418 & 6.86 & 4.861 \\
\hline Lactose & 4.560 & 0.106 & 2.32 & 1.641 & 4.587 & 0.189 & 4.12 & 2.914 \\
\hline Total solids & 0.798 & 0.019 & 2.32 & 1.641 & 0.803 & 0.033 & 4.12 & 2.914 \\
\hline Solids non fat & 11.400 & 0.265 & 2.32 & 1.641 & 11.467 & 0.473 & 4.12 & 2.914 \\
\hline Dry matter & 21.353 & 0.162 & 0.76 & 0.535 & 20.860 & 0.883 & 4.23 & 2.992 \\
\hline \multicolumn{9}{|c|}{ Properties } \\
\hline Specific gravity, $\Gamma^{0}$ & 1.032 & 1.422 & 4.41 & 3.117 & 1.033 & 1.652 & 5.01 & 3.540 \\
\hline Titratable acidity, ${ }^{0} \mathrm{~T}$ & 23.267 & 1.553 & 6.68 & 4.721 & 24.633 & 0.551 & 2.24 & 1.581 \\
\hline Freezing Point, ${ }^{0} \mathrm{C}$ & -598 & 1.069 & 1.79 & 1.265 & -604 & 1.079 & 1.79 & 1.263 \\
\hline Renneting ability, s & 314 & 104.652 & 33.33 & 33.329 & 276 & 42.426 & 15.37 & 15.372 \\
\hline Energy, KJ & 5682 & 64.135 & 1.13 & 0.798 & 5475 & 266.563 & 4.869 & 3.443 \\
\hline \multicolumn{9}{|c|}{ Ratios } \\
\hline Proteins / Fat & 0.607 & 0.040 & 6.52 & 4.608 & 0.647 & 0.022 & 3.34 & 2.359 \\
\hline Proteins / Fat & 0.283 & 0.011 & 3.98 & 2.816 & 0.291 & 0.008 & 2.89 & 2.036 \\
\hline Fat / Dry matter & 0.466 & 0.011 & 2.44 & 1.723 & 0.450 & 0.005 & 1.14 & 0.806 \\
\hline
\end{tabular}


The estimates of the other components for the two breeds are in close ranges; total proteins 6.04-6.08 \%, lactose $-4.56-4.58 \%$, and total solids $-0.08 \%$. Slavov et al. (2006) established that the total proteins in the North-East Bulgarian FineFleece breed and cross-breeds are 6.92 to $7.18 \%$, while in the Trakia Fine-Fleece breed and its crosses with the Australian Merino the range is 5.60-5.83 \% (Slavova et al., 2000, 2001).

The mean values of solids not fat are $11.40 \%$ for the Caucasian and $11.47 \%$ for the Askanian breed, meeting the standards for raw sheep milk to be processed to dairy products. The dry matter content, 21.35 and $20.86 \%$ respectively for the two breeds, is close to that reported by Slavov et al. (2006) for the North-East Bulgarian FineFleece breed and its crosses.

The analysis shows no substantial diversity between the studied breeds in terms of milk properties. The differences in specific gravity, acidity, and cryoscopic point are negligible, yet higher in the Askanian breed. Both milks possess good renneting ability (up to $6 \mathrm{~min}$ ) making them technologically appropriate. Our results are commensurate with those established by Slavov et al. (2006) in the North-East Bulgarian Fine-Fleece breed and its crosses, and superior compared to the renneting properties of the milk of the Trakia Fine-Fleece breed and its crosses with the Australian Merino (Slavova et al., 2000, 2001).

The established ratios among the components, representing the nutritive and technological quality of milk, are close for the two breeds and within the regulation standards for processing.

The results about the technological qualities indicate that the milk processed to Bulgarian Yoghurt is of standard composition and properties (Table 2). Between the two breeds no substantial differences are observed in initial $\left(23.28^{0} \mathrm{~T}\right.$ and $24.63^{\circ} \mathrm{T}$ ) and titratable acidity $1 \mathrm{hr}$ after leavening agent introduction $\left(26.00^{\circ} \mathrm{T}\right.$ и $\left.26.70^{\circ} \mathrm{T}\right)$. As for the titratable acidity $2 \mathrm{hr}$ post leavening and during coagulation, the higher values belong to the Askanian breed, the differences being insignificant though. The coagulation rate of the two milks is practically equal (162 and $160 \mathrm{~s}$ ) and is better than that reported by Slavova et al. (2000) for the Trakia Fine-Fleece breed and its crosses with the Australian Merino (480 to 900 s). The data show similar dynamics of titratable acidity at hour 24 , 48 , and day 10 of end product storage for the two breeds. The results indicate that the milk of the Caucasian and the Askanian breed is a good source for the production of Bulgarian Yoghurt.

Table 2

Technological properties of the milk of Caucasian and Askanian sheep

\begin{tabular}{|c|c|c|c|c|c|c|c|c|}
\hline \multirow{2}{*}{ Traits } & \multicolumn{4}{|c|}{ Caucasian breed } & \multicolumn{4}{|c|}{ Askanian breed } \\
\hline & $\bar{x}$ & $\mathrm{~S}$ & $\mathrm{C}$ & $\mathrm{E}$ & $\bar{x}$ & S & $\mathrm{C}$ & $\mathrm{E}$ \\
\hline Initial TAM, ${ }^{\circ} \mathrm{T}$ & 23.267 & 1.553 & 6.68 & 4.721 & 24.633 & 0.551 & 2.24 & 1.581 \\
\hline TAM $1 \mathrm{hr}$ post leavening, ${ }^{\circ} \mathrm{T}$ & 26.000 & 1.732 & 6.66 & 4.711 & 26.700 & 2.138 & 8.01 & 5.662 \\
\hline TAM $2 \mathrm{hr}$ post leavening, ${ }^{\circ} \mathrm{T}$ & 37.000 & 8.185 & 22.12 & 15.643 & 46.013 & 10.454 & 22.72 & 16.065 \\
\hline TAM during coagulation, ${ }^{\circ} \mathrm{T}$ & 103.333 & 6.658 & 6.44 & 4.556 & 106.000 & 16.062 & 15.15 & 8.749 \\
\hline \multirow[t]{2}{*}{ Coagulation time, min } & 162 & 5.774 & 3.57 & 2.525 & 160 & 16.361 & 10.26 & 5.922 \\
\hline & \multicolumn{8}{|c|}{ Titratable acidity of yoghurt, ${ }^{\circ} \mathrm{T}$} \\
\hline After $24 \mathrm{hr}$ & 132.333 & 8.737 & 6.60 & 4.668 & 129.500 & 15.716 & 12.14 & 7.007 \\
\hline After $48 \mathrm{hr}$ & 140.000 & 10.536 & 7.53 & 5.321 & 148.000 & 19.883 & 13.43 & 7.756 \\
\hline \multirow[t]{2}{*}{ After $10 \mathrm{~d}$} & 156.333 & 9.074 & 5.80 & 4.104 & 166.750 & 12.093 & 7.25 & 4.187 \\
\hline & \multicolumn{8}{|c|}{ White brine cheese production parameters } \\
\hline Yield from 1001 milk, kg & 26.753 & 0.335 & 1.25 & 0.886 & 26.314 & 1.268 & 4.82 & 3.407 \\
\hline Milk needed for $1 \mathrm{~kg}, 1$ & 3.739 & 0.047 & 1.26 & 0.888 & 3.806 & 0.181 & 4.77 & 3.370 \\
\hline
\end{tabular}

TAM - titratable acidity of milk 
The mean yield of white brine cheese out of 1001 of milk is $26.75 \mathrm{~kg}$ for the Caucasian and $26.31 \mathrm{~kg}$ for the Askanian breed, thus $1 \mathrm{~kg}$ of cheese being produced of 3.74 and 3.811 of milk respectively.

\section{CONCLUSIONS}

No substantial differences in the concentrations of the main milk components were observed between the Caucasian and the Askanian breeds. The quality characteristics of the milk meet the standard requirements for raw sheep milk to be processed to dairy products.

The technological properties indicate that the milk of the Caucasian and the Askanian breed is a favourable environment for the development of the leaven bacteria cultures, rendering it an appropriate source for the Bulgarian Yoghurt industry.

\section{REFERENCES}

[1] Бойковски, С. (1995): Проучване върху ефекта от прилаганите методи на развъждане и съешаване при овце от различно продуктивно направление, Докторска дисертация, София, 493.

[2] Бойковски, С., Г. Стефанова, Д. Димитров (2003): Кавказка тънкорунна порода овце в България, Шумен, 189.

[3] Галатов, А. (1991): Влияния скрещивания на качество молока тонкорунных овец, Зоотехния, 10, 28-31.

[4] Димитров, Д. (2001): Проучване върху възможностите за създаване на линия за висока плодовитост при тънкорунни породи овце, Дисертация, София, 121.
[5] Евтимов, Б., Г. Константинов, Й. Василева, Ив. Венев (1972): Приложение на математическите методи в животновъдството, Земиздат, София, 218.

[6] Славов, Р., Г. Михайлова (2006). Химичен и минерален състав на млякото при овце от Североизточнобългарската тънкорунна порода и нейни кръстоски, Животновъдни науки, 1, 39-43.

[7] Славова, П., Г. Михайлова, И. Ценков (2000). Проучване на млечността, състава и свойствата на млякото при овцете от Тракийската тънкорунна порода и кръстоски с Австралийски меринос на първа лактация, Животновъдни науки, 2, 56-61.

[8] Славова, П., Г. Михайлова, И. Ценков (2001): Млечност, състав и свойства на млякото при овце от Тракийска тънкорунна порода и кръстоски с $25 \%$ кръвност от Австралийски меринос на втора лактация, Животновъдни науки, 6, 86-89.

[9] Станков, И., Г. Михайлова, И. Пейчевски, С. Денев, С. Стойчев, М. Петев (1998): Сравнителни проучвания върху млечността и състава на млякото от Южнобългарски коридел и Северокавказка порода овце, Животновъдни науки, Приложение 2, 72-74.

[10] Стефанова, Г. (2000): Проучване ефекта на някои генетични и негенетични фактори върху основните продуктивни признаци на овце от Шуменския тип на Североизточнобългарската тънкорунна порода $u$ Кавказката тънкорунна порода, Дисертация, София, 141.

[11] Чомаков, Х., С. Велев, Т. Димитров, Т. Илиев, Ч. Митева, С. Бойчева (2000): Мляко и млечни продукти, Ст. Загора, 246.

[12] Mroczkovski, S. (1989): Mlecznosc a wyniki użytkowoci welnistey merinosa polskiego, Zootechnika, Bydgoszcz, 18, 59-65.

[13] Pena Blanko, F. (1985): Produkcion laktea en ovejes de rasa Merina durente la fase de amamantamiento, 34, 130:235-247. 